\title{
Allied health - 3007. The biomarker of sublingual immune therapy
}

\author{
Masafumi Sakashita*, Yoshimasa Imoto, Yoko Osawa, Noboru Takahashi, Seita Kubo, Hideyuki Yamamoto, \\ Takechiyo Yamada, Shigeharu Fujieda \\ From 2nd WAO International Scientific Conference (WISC 2012) \\ Hyderabad, India. 6-9 December 2012
}

\section{Background}

Allergic rhinitis (AR) is recognized as a major health problem worldwide. Allergen-specific immunotherapy (SIT) is the only available treatment that can alter the natural course of allergic disease. Recent findings in experimental models of allergic rhinitis suggest that complement $3 \mathrm{a}$ and 5 a regulate the development of maladaptive Th2 and Th17 immunity. We investigated the changes of C3a, C5a, IL-17a in the serum of patients treated by Sublingual immune therapy (SLIT).

\section{Methods}

Symptoms were recorded in the allergy diary. The total symptom medication scores were calculated based on each symptoms and medication. We measured the C3a, C5a, IL-17a levels in serum of the 20 identical subjects by ELISA during 5 years.

\section{Results}

C3a and IL-17a showed significant decrease year by year during 5 years $(\mathrm{p}<0.01)$.

\section{Conclusions}

C3a and IL-17a can be objective biomarker for following up the patients of SLIT.

Published: 23 April 2013

doi:10.1186/1939-4551-6-S1-P183

Cite this article as: Sakashita et al:: Allied health - 3007. The biomarker

of sublingual immune therapy. World Allergy Organization Journal 2013

6(Suppl 1):P183.

The Departments of Otorhinolaryngology Head \& Neck Surgery, University of Fukui, Fukui, Japan

Submit your next manuscript to BioMed Central and take full advantage of:

- Convenient online submission

- Thorough peer review

- No space constraints or color figure charges

- Immediate publication on acceptance

- Inclusion in PubMed, CAS, Scopus and Google Scholar

- Research which is freely available for redistribution
() Biomed Central

\section{Biomed Central}

